Bangladesh J. Bot. 43(1): 27-35, 2014 (June)

\title{
PHYTOSOCIOLOGICAL ANALYSIS ON THE NATIONAL PARK OF THE TEK TEK MOUNTAINS, ŞANLIURFA, TURKEY
}

\author{
ÖMER FARUK KAYA* \\ Department of Biology, Science \& Art Faculty, Harran University-63300, Şanluurfa, Turkey
}

Key words: Tek Tek Mountains, National park, Phytosociology, Southeastern Anatolia, Turkey

\begin{abstract}
Vegetation of the national park of Tek Tek Mountains under the semi-arid and cool Mediterranean climate was analyzed according to 'Braun-Blanquet approach'. The plant associations are classified by considering the characteristic features of the species. In the national park, one new association (Ceraso tortusae - Pistacietum palaestinae) belonging to the shrub vegetation, and two new associations (Achilleo aleppicae - Centaureetum virgatae and Eryngietum cretico - virentis) belonging to steppe vegetation were determined. No similarity among these associations has been identified in the study area with any others introduced before was found. Therefore, these syntaxa are new for science.
\end{abstract}

\section{Introduction}

Southeast Anatolia region of Turkey consists the most indistinct and plain landforms. The topography approaches towards the Southeast Taurus Mountains, which compass the region from north as an arc, elevation increases and landforms become more wavy and hilly. The elevation of Southeast Anatolia plains decreases with a slight slope from the skirts of southeast Taurus Mountains towards the Syrian border. Towards their edges, these plains take the view of plateaus into which valleys are buried and towards middle parts, they look more like a low land.

Located on the southern edges of southeast Taurus Mountains, Harran plain is a graben - $(\sim 30$ $\times 50 \mathrm{~km})$. Tek Tek and Fatik mountains, located in the east and west of Harran plains, are horsts that extend in north-south direction. Tek Tek Mountains, located in a semi-arid region, are subjected to mentioned problems for example, weak vegetation formed as a result of precipitation and deficiency of water resources and usually look like a callow plateau although they have some higher points. These mountains also include a national park (Fig. 1).

In the arid and semi-arid regions, the interventions made by humans on the natural vegetation cause extreme reduction of climax species, dramatical deforestation and anthropogenic steppes becoming widespread and causing the area to appear as if they were the original vegetation of the area. For example, Tek Tek Mountains, while, through the long time most was covered by Pictacia terebinthus subsp. palaestina, they have presently left their places to the uncultivable scar rocky due to the soil erosion as a result of over-woodcutting and over-grazing. However, in the present day, this taxon is only encountered within the national park.

\section{Materials and Methods}

In identifying the plant species, basically Flora of Turkey (Davis 1965-1985, Davis et al. 1988, Güner et al. 2000), as well as some other floras (Zohary and Feinbrun-Dothan 1966-1986, Towsend and Guest 1966-1985) and other studies (Adıgüzel and Aytaç 2001, Kaya and Ertekin 2009) were consulted.

Phytosociological nomenclature of the defined syntaxa was performed according to Weber et al. (2000). Detailed scale of Frey and Lösch (1998) was used in order to determine the abundancecover values of the species $(r=1$ individual, also rare outside the relevé (=quadrat),

\footnotetext{
*Author for correspondence: <phytosociologist@gmail.com>.
} 
small plant); $+=2-5$ (small) individuals, cover $<5 \% ; 1=6-50$ individuals, cover $<5 \%$; or few larger individuals (often given as $1-5$ ) with a cover up to $5 \% ; 1 \mathrm{~m}=$ many individuals $(>50$ ), cover $<5 \% ; 2 \mathrm{a}=$ cover $5-12.4 \% ; 2 \mathrm{~b}=$ cover $12.5-25 \% ; 3=$ cover $25-50 \% ; 4=$ cover $50-$ $75 \% ; 5=$ cover $75-100 \%)$.

Evaluation of floristic tables in terms of phytosociology was made by using Braun-Blanquet (1965) approach. Syntaxa belonging to shrub vegetation were classified depending on the studies of Braun-Blanquet et al. (1952), Mucina (1997), and Quézel et al. (1978); whereas, syntaxa belonging to steppe vegetation were classified depending on the studies of Quézel (1973), Akman et al. (1985) and Kaya and Ketenoğlu (2010). Tables belonging to associations were given together with the upper syntaxonomic units in which they were placed.

Soil samples were collected from the survey area so as to determine edaphic features of plant associations and were conducted according to Tüzüner (1990) at Soil, Fertilizer and Water Resources Central Research Institute. Climatic data for the study area were obtained from Directorate General of Meteorology (Anon. 2010). Ombrothermic climate (precipitationtemperature) diagram was drawn according to the Gaussen method (Bagnouls and Gaussen 1953).

\section{Results and Discussion}

The soil on Tek Tek Mountains which was disintegrated in the tropical conditions of Tertiary era was wiped away with the rains in Pluvial period resulted because of climatic changes in Pleistocene. The Harran basin is filled with this soil. The plateau surface was literally ripped up by rivers due to the increasing rainfall of Pleistocene. Surface of the plateau was disintegrated with multiple drought valleys, because the area is composed of thick limestone layers and the severe evaporation occurs during summer months (Güzel 1998).

Red-brown soil is seen in the study area. The land surface is covered by coarse gravel, rubble and stones. These soils are medium-deep, clayed, clayed-loamy and rocky and are found in semiarid climates (Anon. 1995). According to Tüzüner (1990), the soils in study area are generally alkaline, saltless, highly limey and rich in phosphorus and potassium (Table 1).

Table 1. Physicochemical properties of the soils of the study area.

\begin{tabular}{|c|c|c|c|c|c|c|c|c|c|c|}
\hline Association & $\begin{array}{c}\text { Relevé } \\
\text { no. }\end{array}$ & Texture & $\begin{array}{c}\text { Saturation } \\
(\%)\end{array}$ & $\begin{array}{c}\mathrm{EC}, \\
\mathrm{dS} / \mathrm{m}\end{array}$ & $\mathrm{pH}$ & $\begin{array}{c}\mathrm{CaCO}_{3} \\
(\%)\end{array}$ & $\begin{array}{c}\mathrm{P}_{2} \mathrm{O}_{5} \\
(\mathrm{~kg} / \mathrm{da})\end{array}$ & $\begin{array}{c}\mathrm{K}_{2} \mathrm{O} \\
(\mathrm{kg} / \mathrm{da})\end{array}$ & $\begin{array}{c}\text { Organic } \\
\text { matter }(\%)\end{array}$ & $\begin{array}{c}\mathrm{N} \\
(\%)\end{array}$ \\
\hline \multirow{4}{*}{$\begin{array}{l}\text { Ceraso } \\
\text { tortusae - } \\
\text { Pistacietum } \\
\text { palaestinae }\end{array}$} & 1 & $\mathrm{CL}$ & 64 & 1.045 & 8 & 14.2 & 1.4 & 123.2 & 2.5 & 0.13 \\
\hline & 2 & $\mathrm{C}$ & 77 & 1.040 & 7.8 & 4.9 & 6 & 157.9 & 2.8 & 0.14 \\
\hline & 5 & $\mathrm{C}$ & 71 & 0.990 & 7.8 & 3.2 & 5.5 & 123.1 & 2.6 & 0.13 \\
\hline & 8 & $\mathrm{C}$ & 76 & 1.055 & 7.9 & 1.9 & 1.1 & 138.1 & 2.7 & 0.14 \\
\hline Achilleo & 14 & CL & 55 & 1.032 & 7.9 & 24.8 & 1.9 & 102.2 & 1.5 & 0.07 \\
\hline $\begin{array}{l}\text { aleppicae - } \\
\text { Centaureetum } \\
\text { virgatae }\end{array}$ & 18 & CL & 66 & 1.107 & 8 & 1.7 & 0.8 & 95.6 & 1.9 & 0.10 \\
\hline Eryngietum & 22 & $\mathrm{CL}$ & 62 & 1.057 & 7.7 & 1.5 & 0.7 & 92.3 & 1.3 & 0.07 \\
\hline $\begin{array}{l}\text { cretico - } \\
\text { virentis }\end{array}$ & 26 & $\mathrm{CL}$ & 53 & 1.063 & 7.8 & 1.2 & 1.5 & 91.7 & 1 & 0.04 \\
\hline
\end{tabular}

Texture legend: C: clay, L: loamy, CL: clay-loamy.

The saturation percentage and the other relevant data of Table 1 reveals that Ceraso tortusae Pistacietum palaestinae spreads usually on soil with loamy and rarely clay-loamy texture and other two associations (Achilleo aleppicae - Centauretum virgatae and Eryngietum cretico virenti) spread on soil only with clay-loamy texture. The soil of all the three associations in the 
area slightly alkaline in terms of $\mathrm{pH}$ and can be classified as saltless soil in terms of electrical conductivity (EC).

Most of the soil of Turkey is limy (Gedikoğlu 1990). In the present investigation, lime contents of the soil where associations spread show different from each other. Ceraso tortusae Pistacietum palaestinae is found on limy and medium-limy soil, Achilleo aleppicae - Centauretum virgatae is found on limy and highly limy soil, and Eryngietum cretico - virenti is found on limy soil.

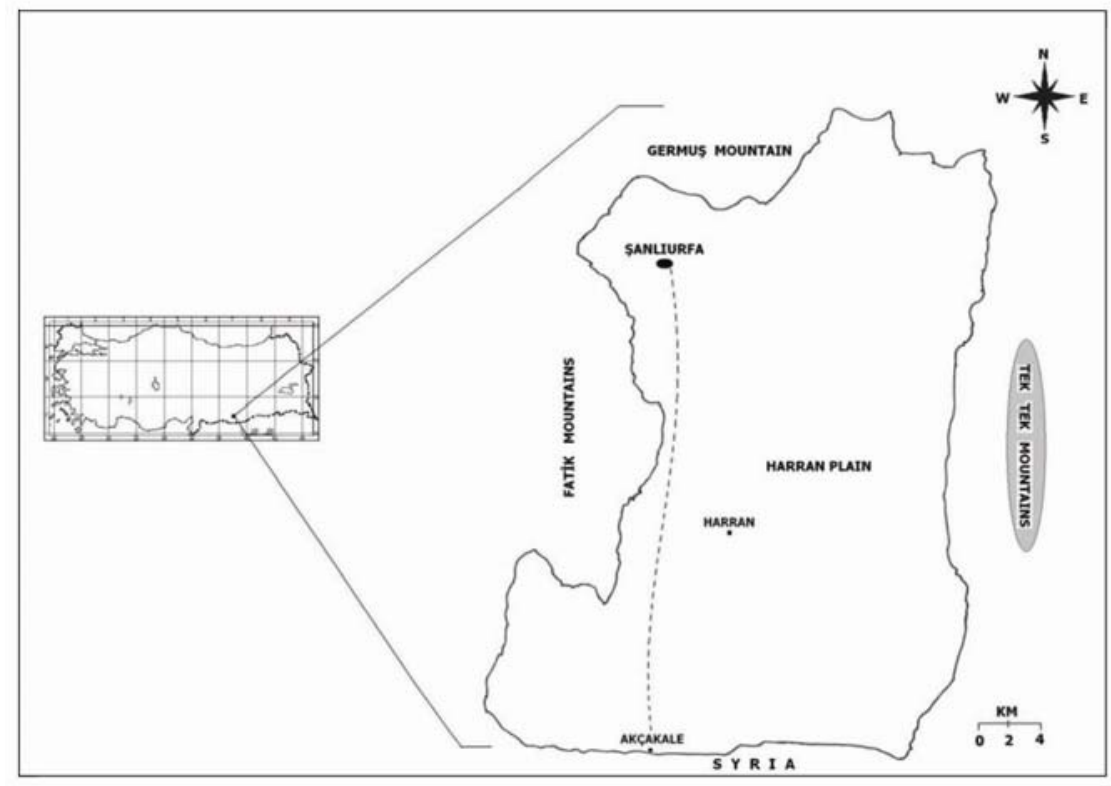

Fig. 1. Location of Tek Tek mountains in Şanlıurfa.

Soil phosphorus is lacking in majority part of Turkey (Eyüpoğlu 1999). In the present investigation, phosphorus ratio is usually lower in the soil of Achilleo aleppicae - Centauretum virgatae and Eryngietum cretico - virenti, whereas it relevés 1 and 5 of Ceraso tortusae Pistacietum palaestinae phosphor in ratio is very low, in relevé 2 low and in relevé 8 high phosphor ratios are seen.

Potassium was variable in different coverages (Table 1) but it was high elsewhere throughout Turkey (Eyüpoğlu 1999). In terms of plant efficiency, there is no potassium supply shortage in the association areas. Turkish soil generally lacks organic matter (Eyüpoğlu 1999). In the present investigation, it has been seen that organic matter is low in Achilleo aleppicae - Centauretum virgatae and Eryngietum cretico - virenti, whereas it is medium in Ceraso tortusae - Pistacietum palaestinae (Table 1). The nitrogen content was detected to be very low only in relevé 14 of Achilleo aleppicae - Centauretum virgatae, whereas it was determined that usually amount of nitrogen is sufficient in other associations soils.

It was observed that the soil parameters obtained from the analysis were at optimal rate for the plant growth. It can be said that the vegetation of the national park depends on other biotic and abiotic factors rather than the soil.

According to the meteorological data of Şanluurfa meteorology station (Anon. 2010), precipitation regime is in the form of W.Sp.A.Sm (winter, spring, autumn, summer) and eastern 
Mediterranean type 1. In the study area, semi-arid and cool Mediterranean climate can be seen. In Şanlıurfa, the dry season takes six months from the late April - early May and to the early November, and precipitation season takes another six months from early November to early May (Fig. 2).

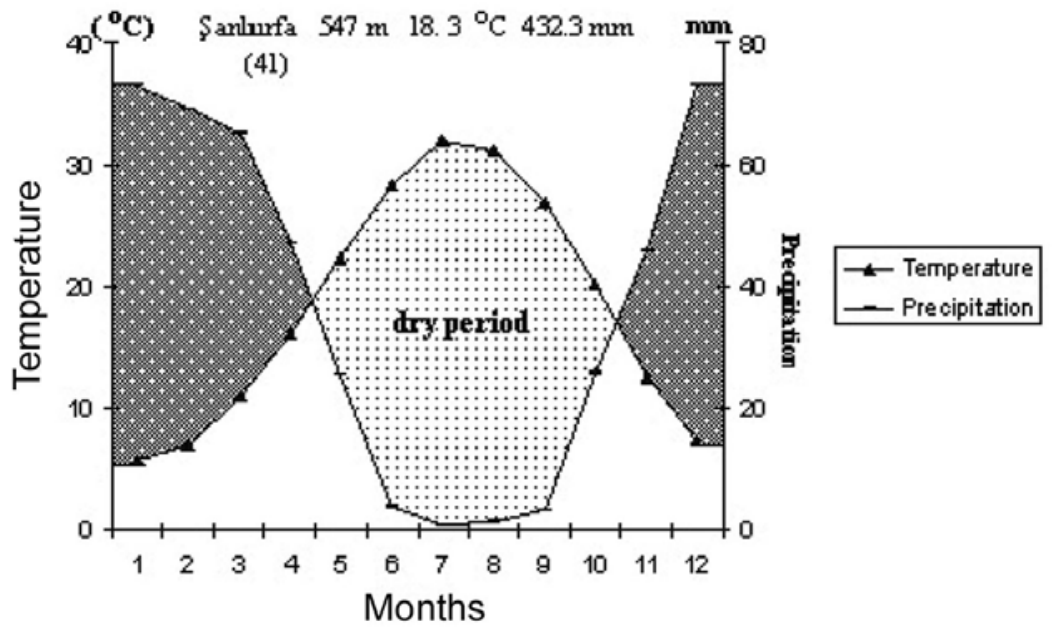

Fig. 2. Ombrothermic diagram of Şanlıurfa.

Tek Tek Mountains are generally dominated by steppe vegetation formed by regressive succession. Most of Tek Tek Mountains were covered for long years with shrub vegetation which consisted of Pistacia terebinthus subsp. palaestina. It was exposed to erosion due to excessive deforestation and overgrazing and paved the way for non-agricultural naked rocky and steppe.

According to the floristic study conducted by Kaya and Ertekin (2009) in this preserved area, 265 taxa were recorded and generally these taxa were found in other parts of Tek Tek Mountains during this study as well. Some reasons have prevented Tek Tek Mountains to have a rich floristic structure, such as small difference in altitude $(550-800 \mathrm{~m})$, rough structure of the area, lack of a microclimatic zone and anthropogenic effects. Ceraso tortusae - Pistacietum palaestinae, which covers the entire hillsides of valleys, which lie to the north of the national park represents a shrub vegetation which is destroyed from place to place. Pistacia terebinthus subsp. palaestina, which determines the physiognomy of the association, is an eastern Mediterranean element that spreads over the eastern part of Mediterranean basin and is one of the permanent elements of maquis.

Two steppe associations (Achilleo aleppicae - Centaureetum virgatae and Eryngietum cretico - virentis) described in the national park. Achilleo aleppicae - Centaureetum virgatae spreads especially over the northward and north-eastward hillside of the marble quarry. Centaurea virgata is dominant on the physiognomy of the association. This taxon is an Irano-Turanian element and shows wide distribution in northwest, east and especially in central areas of Anatolia in Turkey (Davis 1965-1985). The association is secondary vegetation formed as a result of the anthropogenic degeneration of Pistacia population. The evidence for this can be provided as follows: Pistacia terebinthus subsp. palaestina, Cerasus microcarpa subsp. tortusa, and Ficus carica subsp. rupestris are found as individuals here and there in somewhat rocky slope hillsides within the diffusion area of the association. Eryngium campestre subsp. virens determines the physiognomy of Eryngietum cretico - virentis. It can be generally found in all arid habitats in 
Turkey. This is the most widely spread association in the national park area. It displays a rather weak diffusion outside the stony areas.

Table 2. Ceraso tortusae - Pistacietum palaestinae ass. nova. (Holotypus: relevé 8).

\begin{tabular}{|c|c|c|c|c|c|c|c|c|c|c|c|c|}
\hline & Relevé no. & 1 & 2 & 3 & 4 & 5 & 6 & 7 & 8 & 9 & 10 & \\
\hline & Size of plot $\left(\mathbf{m}^{2}\right)$ & 400 & 400 & 400 & 400 & 400 & 400 & 400 & 400 & 4004 & 400 & \\
\hline & Parent rock & LS & LS & LS & LS & LS & LS & LS & LS & LS & LS & 巳 \\
\hline & Inclination $\left({ }^{\circ}\right)$ & 5 & 5 & 10 & 5 & 25 & 40 & 20 & 30 & 30 & 40 & $\bar{\Xi}$ \\
\hline & Altitude (m) & 550 & 570 & 630 & 590 & 6806 & 680 & 690 & 670 & 6506 & 690 & a \\
\hline & Exposition & W & S & $\mathrm{N}$ & S & $\mathrm{N}$ & $\mathrm{N}$ & $\mathrm{N}$ & $\mathbf{N}$ & $\mathrm{S}$ & $\mathrm{N}$ & \\
\hline & Coverage (\%) & 75 & 70 & 80 & 65 & 80 & 75 & 80 & 85 & 70 & 70 & \\
\hline \multicolumn{13}{|c|}{ LF } \\
\hline \multicolumn{13}{|c|}{ Differential and characteristic species of the association } \\
\hline $\mathrm{Ph}$ & Pistacia terebinthus subsp. palaestina & 4 & 4 & 5 & 3 & 5 & 4 & 5 & 5 & 5 & 4 & $\mathrm{~V}$ \\
\hline $\mathrm{Ph}$ & Cerasus microcarpa subsp. tortusa & + & 1 & + & & 1 & + & & 1 & + & & IV \\
\hline \multirow[t]{2}{*}{$\mathrm{H}$} & Centaurea obtusifolia & & & $\mathrm{r}$ & & + & + & 1 & 1 & & $\mathbf{r}$ & III \\
\hline & Characteristic species of Quercion calliprin & & & & & & & & & & & \\
\hline \multirow[t]{2}{*}{$\mathrm{H}$} & Eryngium falcatum & & + & & + & & + & & + & & + & III \\
\hline & Characteristic species of Quercetalia ilicis & & & & & & & & & & & \\
\hline \multirow[t]{2}{*}{ G } & Anemone coronaria & + & + & & & & + & & + & + & & III \\
\hline & Characteristic species of Quercetea ilicis & & & & & & & & & & & \\
\hline \multirow[t]{2}{*}{$\mathrm{Ph}$} & Ficus carica subsp. rupestris & & + & & & & + & + & + & & + & III \\
\hline & Companions & & & & & & & & & & & \\
\hline $\mathrm{Th}$ & Lagoecia cuminoides & $1 \mathrm{~m}$ & $2 \mathrm{a}$ & $1 \mathrm{~m}$ & 1 & $1 \mathrm{~m}$ & & 1 & $1 \mathrm{~m}$ & & 1 & IV \\
\hline Th & Crepis sancta & + & + & + & & 1 & & & + & + & + & IV \\
\hline Th & Trifolium stellatum var. $s$. & $1 \mathrm{~m}$ & 1 & + & + & & + & & + & & + & IV \\
\hline $\mathrm{Ch}$ & Teucrium polium & + & + & + & + & & & + & 1 & 1 & & IV \\
\hline $\mathrm{Th}$ & Ziziphora capitata & + & & & + & + & + & + & + & & + & IV \\
\hline Th & Trifolium speciosum & + & + & & + & & + & + & + & + & & IV \\
\hline $\mathrm{H}$ & Telephium oligospermum & & & + & + & + & & + & + & + & & III \\
\hline $\mathrm{H}$ & Delphinium kurdicum & + & & + & & + & + & & + & & + & III \\
\hline $\mathrm{H}$ & Salvia palaestina & & + & & + & & + & & + & + & + & III \\
\hline $\mathrm{Th}$ & Trifolium scabrum & & + & + & + & + & + & + & & & & III \\
\hline $\mathrm{H}$ & Tragopogon longirostris var. $l$. & & + & 1 & & + & & & 1 & + & & III \\
\hline $\mathrm{H}$ & Onopordum bracteatum var. $b$. & + & & & + & & + & & + & + & & III \\
\hline $\mathrm{Th}$ & Legousia speculum-veneris & 1 & & & + & & & + & + & + & & III \\
\hline Th & Rhagadiolus stellatus var. $s$. & + & & 1 & & & & & + & + & + & III \\
\hline $\mathrm{H}$ & Salvia bracteata & & & + & & + & + & & + & + & & III \\
\hline Th & Clypeola johnthlaspi & + & + & & & + & & + & + & & & III \\
\hline $\mathrm{Th}$ & Biscutella didyma & + & + & + & + & & & & & & & II \\
\hline Th & Cicer pinnatifidium & & & & & + & + & & + & + & & II \\
\hline $\mathrm{H}$ & Scorzonera mollis subsp. szowitzii & & & & + & + & + & + & & & & II \\
\hline Th & Linaria chalepensis var. $c$. & & & + & & & + & + & & + & & II \\
\hline $\mathrm{Ph}$ & Crataegus aronia var. $a$. & & 1 & & + & & & & & + & & II \\
\hline $\mathrm{H}$ & Trigonosciadium viscidulum & & & & & & & & + & + & + & II \\
\hline $\mathrm{H}$ & Euphorbia oxyodonta & + & + & & & + & & & & & & II \\
\hline $\mathrm{H}$ & Hypericum retusum & & + & & & & & + & + & & & II \\
\hline Th & Onobrychis aequidentata & & & & & + & & & + & & + & II \\
\hline $\mathrm{H}$ & Serratula cerinthifolia & & & & + & & + & & + & & & II \\
\hline $\mathrm{H}$ & Verbascum kotschyi & + & + & + & & & & & & & & II \\
\hline $\mathrm{Th}$ & Trifolium leucanthum & & & + & & & & & + & & & I \\
\hline G & Crocus pallasii subsp. turcicus & + & + & & & & & & & & & I \\
\hline $\mathrm{H}$ & Haplophyllum thesioides & & & & & & & + & + & & & I \\
\hline $\mathrm{H}$ & Leucocyclus formosus subsp. amanicus & + & & & + & & & & & & & I \\
\hline
\end{tabular}

When the chorology of the taxa detected in the national park are examined, they are usually titled as Irano-Turanian, Mediterranean and East Mediterranean. This is an evidence that the study area is in Irano-Turanian phytogeographical region (Davis 1965-1985). The fact that 
Mediterranean and East Mediterranean elements occupy second and third ranks and that two of the three detected associations are dominated by taxa with Mediterranean and East Mediterranean elements verifies the view that Mediterranean vegetation in the past extended until southeast Anatolia.

Table 3. Achilleo aleppicae - Centaureetum virgatae ass. nova (Holotypus: relevé 14).

\begin{tabular}{|c|c|c|c|c|c|c|c|c|c|c|c|c|}
\hline & Relevé no. & 11 & 12 & 13 & 14 & 15 & 16 & 17 & 18 & 19 & 20 & \\
\hline & Size of plot $\left(\mathbf{m}^{2}\right)$ & 50 & 50 & 50 & $\mathbf{5 0}$ & 50 & 50 & 50 & 50 & 50 & 50 & \\
\hline & Parent rock & LS & LS & LS I & LS & LS & LS & LS & LS & LS & LS & \\
\hline & Inclination $\left({ }^{\circ}\right)$ & 5 & 5 & 10 & 15 & 10 & 30 & 15 & 15 & 20 & 15 & \\
\hline & Altitude (m) & 512 & 543 & 6106 & 620 & 628 & 640 & 639 & 680 & 660 & 652 & छ \\
\hline & Exposition & $\mathrm{S}$ & $\mathrm{S}$ & $\mathrm{S}$ & $\mathbf{N}$ & NE & NE & $\mathrm{N}$ & $\mathrm{N}$ & $\mathrm{N}$ & W & $\overline{\breve{g}}$ \\
\hline & Coverage (\%) & 40 & 60 & 60 & 70 & 60 & 65 & 65 & 70 & 60 & 40 & 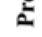 \\
\hline \multicolumn{13}{|c|}{ (6) } \\
\hline \multicolumn{13}{|c|}{ Differential and characteristic species of the association } \\
\hline $\mathrm{H}$ & Centaurea virgata & 3 & 3 & 4 & 5 & 5 & 4 & 4 & 4 & 5 & 3 & V \\
\hline $\mathrm{H}$ & Achillea aleppica subsp. $a$. & & & 1 & 1 & + & & & 1 & & + & III \\
\hline \multicolumn{13}{|c|}{ Characteristic species of Astragalo erythrotaeni-Gundelion armatae } \\
\hline $\mathrm{H}$ & Torilis leptocarpa & & + & & + & & & + & + & + & & III \\
\hline $\mathrm{H}$ & Gundelia tournefortii var. armata & + & & + & + & & + & & & & + & III \\
\hline \multicolumn{13}{|c|}{ Characteristic species of Onobrychido armenae-Thymetalia lecostomi } \\
\hline $\mathrm{H}$ & Paronychia kurdica subsp. $k$. var. $k$. & & + & + & + & & & & & & & II \\
\hline \multicolumn{13}{|c|}{ Characteristic species of Astragalo-Brometea } \\
\hline Th & Xeranthemum annuum & + & & + & 1 & 1 & + & & + & + & & IV \\
\hline $\mathrm{Ch}$ & Teucrium polium & + & & 1 & + & + & & + & + & & + & IV \\
\hline $\mathrm{H}$ & Ajuga chamaepitys subsp. c. var. $c$. & & + & & + & & & + & + & & & II \\
\hline $\mathrm{H}$ & Poa bulbosa & & + & & & & + & & + & & + & II \\
\hline Th & Ziziphora tenuior & & + & & + & & & & & & + & II \\
\hline $\mathrm{Th}$ & Bromus japonicus subsp. $j$. & & & & + & + & & & + & & & II \\
\hline \multicolumn{13}{|c|}{ Companions } \\
\hline Th & Aegilops triuncialis subsp. $t$. & & + & 1 & 1 & + & & + & 1 & 1 & + & IV \\
\hline Th & Ziziphora capitata & 1 & & + & + & & + & & + & + & + & IV \\
\hline Th & Tordylium hasselquistiae & & + & + & & + & & + & & + & & III \\
\hline $\mathrm{H}$ & Pimpinella corymbosa & + & & & + & & & + & & + & & II \\
\hline $\mathrm{H}$ & Achillea membranacea & & & + & + & & + & & + & & & II \\
\hline $\mathrm{H}$ & Ballota saxatilis subsp. $s$. & & + & + & & & + & & + & & & II \\
\hline $\mathrm{H}$ & Astragalus aleppicus & & + & & + & & + & & & + & & II \\
\hline $\mathrm{Ch}$ & Thymbra spicata var. $s$. & & + & & + & & & + & & & + & II \\
\hline $\mathrm{H}$ & Fibigia eriocarpa & & & & + & + & + & & & & & II \\
\hline Th & Onobrychis crista-galli & & & + & & + & & & + & & & II \\
\hline $\mathrm{H}$ & Centaurea stapfiana & & & + & & & + & & & & + & II \\
\hline $\mathrm{H}$ & Phlomis bruguieri & & & + & & & + & & & & + & II \\
\hline $\mathrm{H}$ & Phlomis kurdica & & + & & & & & & + & & + & II \\
\hline Th & Xeranthemum longipapposum & + & & + & & + & & & + & & & II \\
\hline $\mathrm{H}$ & Scutelleria orientalis subsp. haussknechtii & & + & & + & & & & + & & & II \\
\hline Th & Ononis viscosa subsp. breviflora & & & & + & & + & & & & + & II \\
\hline $\mathrm{Th}$ & Euphorbia chamaesyce & & & + & & & & & + & & & I \\
\hline Th & Picris kotschyi & & & & + & & & + & & & & I \\
\hline $\mathrm{H}$ & Sideritis libanotica subsp. kurdica & & & & + & & & + & & & & I \\
\hline Th & Anacyclus nigellifolius subsp. orientalis & & & + & & & & + & & & & I \\
\hline $\mathrm{H}$ & Achillea wilhelmsii & & + & & & & + & & & & & I \\
\hline $\mathrm{H}$ & Anarrhinum orientale & & & & + & & & + & & & & I \\
\hline $\mathrm{G}$ & Asphodeline damascena subsp. gigantea & & & + & & & & + & & & & I \\
\hline $\mathrm{G}$ & Hyacinthella nervosa & & & & + & & & & & & + & I \\
\hline Th & Hedypnois cretica & & & & + & & & & & & & I \\
\hline $\mathrm{H}$ & Johrenia dichotoma subsp. $d$. & & & + & & + & & & & & & I \\
\hline
\end{tabular}

According to Zohary (1973), Irano-Turanian phytogeographical region is dominated by hemicryptophtyes and chamaephytes. When the life forms of the taxa detected in national park are examined according to Raunkiaer (1934), therophytes occupy the first rank in terms of ratio, but 
hemicrytophytes determine the physiognomy which is actually at the second rank; this fact verifies this viewpoint.

Table 4. Eryngietum cretico - virentis ass. nova (Holotypus: relevé 22).

\begin{tabular}{|c|c|c|c|c|c|c|c|c|c|c|c|c|}
\hline & Relevé no. & 21 & 22 & 23 & 24 & 25 & 26 & 27 & 28 & 29 & 30 & \\
\hline & Size of plot $\left(\mathrm{m}^{2}\right)$ & 50 & $\mathbf{5 0}$ & 50 & 50 & 50 & 50 & 50 & 50 & 50 & 50 & \\
\hline & Parent rock & LS & LS & LS & LS & LS & LS & LS & LS & LS & LS & \\
\hline & Inclination $\left({ }^{\circ}\right)$ & 2 & 5 & 2 & 2 & 2 & 2 & 3 & 2 & 3 & 2 & \\
\hline & Altitude (m) & W & $\mathbf{W}$ & W & W & $\mathrm{W}$ & SE & $\mathrm{E}$ & W & $\mathrm{E}$ & $\mathrm{E}$ & \\
\hline & Exposition & $\mathrm{E}$ & $\mathbf{E}$ & $\mathrm{E}$ & $\mathrm{E}$ & $\mathrm{E}$ & $\mathrm{E}$ & $\mathrm{E}$ & $\mathrm{E}$ & $\mathrm{E}$ & $\mathrm{E}$ & \\
\hline & Coverage (\%) & 60 & 65 & 40 & 55 & 60 & 50 & 40 & 50 & 50 & 40 & 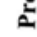 \\
\hline \multicolumn{13}{|c|}{ LF } \\
\hline \multicolumn{13}{|c|}{ Differential and characteristic species of the association } \\
\hline $\mathrm{H}$ & Eryngium campestre subsp. virens & 4 & 4 & 4 & 3 & 4 & 4 & 3 & 3 & 4 & 3 & 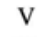 \\
\hline $\mathrm{H}$ & Eryngium creticum & 1 & $1 \mathrm{~m}$ & 1 & $1 \mathrm{~m}$ & + & + & + & 1 & + & 1 & $\mathrm{~V}$ \\
\hline \multicolumn{13}{|c|}{ Characteristic species of Astragalo erythrotaeni-Gundelion armatae } \\
\hline $\mathrm{H}$ & Gundelia tournefortii var. armata & + & 1 & + & & + & & & & 1 & & II \\
\hline \multicolumn{13}{|c|}{ Characteristic species of Onobrychido armenae-Thymetalia lecostomi } \\
\hline $\mathrm{H}$ & Paronychia kurdica subsp. $k$. var. $k$. & & + & & & + & & & & & & I \\
\hline \multicolumn{13}{|c|}{ Characteristic species of Astragalo-Brometea } \\
\hline Th & Xeranthemum annuum & & + & & + & + & & + & & + & & III \\
\hline $\mathrm{H}$ & Ajuga chamaepitys subsp. chia var. $c$. & + & + & & & & + & & + & & & II \\
\hline Th & Bromus japonicus subsp. $j$. & & + & & + & & & & + & & & 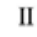 \\
\hline \multicolumn{13}{|c|}{ Companions } \\
\hline $\mathrm{H}$ & Astragalus diphtherites var. $d$. & + & 1 & + & + & & 1 & & + & & + & IV \\
\hline $\mathrm{H}$ & Echinops orientalis & & + & + & + & & + & + & & + & + & IV \\
\hline Th & Aegilops triuncialis subsp. $t$. & + & 1 & & & & + & $1 \mathrm{~m}$ & + & & + & III \\
\hline Th & Echinaria capitata & & + & 1 & 1 & + & + & & & + & & III \\
\hline Th & Ziziphora capitata & & 1 & + & + & & 1 & + & & & + & III \\
\hline Th & Trifolium pauciflorum & + & + & & & & + & & + & + & & III \\
\hline Th & Trigonella spruneriana var. $s$. & + & + & & & + & + & & & & + & III \\
\hline $\mathrm{Th}$ & Avena sterilis subsp. $s$. & & & & + & + & + & + & & & + & III \\
\hline $\mathrm{Th}$ & Erodium cicutarium subsp. $c$. & & + & & + & & & + & + & & + & III \\
\hline Th & Trifolium scabrum & & 1 & & + & + & & & & + & & II \\
\hline $\mathrm{Th}$ & Medicago coronata & & & + & & 1 & & + & + & & & II \\
\hline $\mathrm{Th}$ & Scandix stellata & & + & & + & & & + & & & + & II \\
\hline Th & Trigonella filipes & + & & & & & + & + & & & + & II \\
\hline $\mathrm{H}$ & Dianthus zonatus var. hypochlorus & & + & & & + & & & + & + & & II \\
\hline Th & Xeranthemum longipapposum & & & + & + & + & & & + & & & II \\
\hline $\mathrm{H}$ & Hordeum bulbosum & & + & & & + & & + & & & + & II \\
\hline $\mathrm{Ch}$ & Thymbra spicata var. $s$. & + & & & & + & & & + & & + & II \\
\hline Th & Cephalaria setosa & & + & & + & + & & & & + & & II \\
\hline G & Gagea reticulata & + & + & & & & & & & + & + & II \\
\hline $\mathrm{Th}$ & Trigonella mesopotamica & & + & & & + & + & & & + & & II \\
\hline Th & Alyssum szowitsianum & + & & & & + & & + & & & & II \\
\hline Th & Trifolium cherleri & & & & + & + & + & & & & & II \\
\hline G & Gladiolus atroviolaceus & + & & & & & & + & & & + & II \\
\hline Th & Cerastium dichotomum subsp. $d$. & + & & & & + & & & + & & & II \\
\hline Th & Erodium ciconium & + & & & + & + & & & & & & II \\
\hline $\mathrm{H}$ & Sanguisorba minor subsp. magnolii & & + & & & + & & & & & & I \\
\hline Th & Crepis foetida subsp. commutata & + & & & & & + & & & & & I \\
\hline $\mathrm{H}$ & Eryngium glomeratum & + & & & & & + & & & & & I \\
\hline Th & Veronica hederifolia & & & + & & & & & & + & & I \\
\hline $\mathrm{H}$ & Aristolochia bottae & & & & & + & & & & & & $\mathrm{I}$ \\
\hline
\end{tabular}

Natural vegetation of the national park area, which was surrounded by villages and cultivated areas in the past, has been rapidly destroyed due to overgrazing and anthropogenic factors, and in these areas naked lands occurred with the contributing effect of wind erosion. Tek Tek Mountains 
consist of secondary steppe vegetation in general except for the shrub vegetation in an area with storable vegetation as it was under the impact of such biotic and abiotic factors.

As a result, in the national park, one association belonging to shrub vegetation and two associations belonging to steppe vegetation have been defined. All of these syntaxa are new to science because no similarity of these syntaxa with any others introduced before has ever been found. These syntaxa and their upper syntaxonomic units are shown below.

\section{Shrub vegetation}

Class: Quercetea ilicis Br.-Bl. ex A. Bolòs y Vayreda 1950

Order: Quercetalia ilicis Br.-B1. ex Molin. 1934

Alliance: Quercion calliprini (Zohary 1962) Quézel, Barbéro \& Akman 1978

Association: Ceraso tortusae - Pistacietum palaestinae ass. nova

\section{Steppe vegetation}

Class: Astragalo microcephali - Brometea tomentelli Quézel 1973

Order: Onobrychido armenae - Thymetalia leucostomi Akman, Ketenoğlu \& Quézel 1985

Alliance: Astragalo erythrotaeni - Gundelion armatae Kaya \& Ketenoğlu 2010

Association: Achilleo aleppicae - Centaureetum virgatae ass. nova

Association: Eryngietum cretico - virentis ass. nova

\section{References}

Adıgüzel N and Aytaç Z 2001. Flora of Ceylanpınar state farm (Şanlıurfa-Turkey). Flora Medit. 11: 333-361.

Akman Y, Ketenoğlu O and Quézel P 1985. A new syntaxon from Central Anatolia. Ecol. Medit. 11(2-3): 111-121.

Anonymous 1995. Şanlıurfa İli Arazi Varlığı. K.H.G.M. yayınları, Ankara, pp. 95.

Anonymous 2010. Observation Data of Şanliurfa Weather Station. Turkish State Meteorological Service, Ankara.

Bagnouls F and Gaussen H 1953. Saison sèche et índice xérothermique. Bull. Soc. Hist. Nat. Toulouse, 88: 193-239.

Bolòs y Vayreda A 1950. Vegetación de las comarcas barcelonesas, descripción geobotánica y catálogo florístico, según estudios efectuados por el propio autor y por Oriol de Bolós y Capdevila (Firts Edition). Instituto Español de Estudios Mediterráneos, Barcelona. pp. 579.

Braun-Blanquet J 1965. Plant Sociology (translated by G.D. Fuller \& H.S.Conard). McGraw-Hill, New York. pp. 439.

Braun-Blanquet J, Roussine N and Nègre R 1952. Les Groupements Végétaux de la France Méditerranéenne. CNRS, Service de la Carte des Group. Végétaux, Montpellier. pp. 289.

Davis PH (Ed), 1965-1985. Flora of Turkey and the East Aegean Islands, Vols. 1-9. Edinburgh University Press, Edinburgh.

Davis PH, Mill RR and Tan K (Eds) 1988. Flora of Turkey and the East Aegean Islands, Vol. 10 (supplement). Edinburgh University Press, Edinburgh.

Frey W and Lösch R 1998. Lehrbuch der Geobotanik: Pflanzen und Vegetation in Raum und Zeit. Gustav Fischer, Stuttgart. pp. 436.

Eyüpoğlu F 1999. Türkiye Topraklarının Verimlilik Durumları. Toprak ve Gübre Araştırma Enstitüsü Yayınları, Ankara, pp. 122.

Gedikoğlu İ 1990. Laboratuar Analizlerinin Gübre Önerilerinde Kullanılması ve Halen Kullanılan Kriterler. Şanlıurfa Araştırma Enstitüsü Müdürlüğü Yayınları, Şanlıurfa, pp. 57. 
Güner A, Özhatay N, Ekim T and Başer KHC 2000. Flora of Turkey and the East Aegean Islands, Vol. 11 (supplement). Edinburgh University Press, Edinburgh.

Güzel A 1998. Physical Geography Investigations at the West of Tek Tek Mountains "Master Thesis". Gazi University Graduate School of Social Sciences, Department of Geography, Ankara. pp. 87.

Kaya ÖF and Ertekin AS 2009. Flora of the protected area at the Tek Tek mountains (Şanlıurfa-Turkey). The Herb J. Syst. Bot. 16(2): 79-96.

Kaya ÖF and Ketenoğlu O 2010. A syntaxonomical and synecological research on the steppe vegetation of the Karacadağ mountain (Şanlıurfa/Diyarbakır). Ecol. Medit. 36(1): 45-62.

Molinier, R. 1934. Études phytosociologiques et écologiques en Provence occidentale. Ann. Mus. Hist. Nat. Marseille, 27: 1-274.

Mucina L 1997. Conspectus of classes of European vegetation. Folia Geobot. Phytotax. 32: 117-172.

Quézel P 1973. Contribution à l'étude phytocoenologique du massif du Taurus. Phytocoenologia. 1(2): 131222.

Quézel P, Barbero M and Akman Y 1978. L'interprétation phytosociologique des groupements forestiers dans le bassin méditerranéen oriental. Phytocoenologia. 2: 329-352.

Raunkiaer C 1934. The Life Forms of Plants and Statistical Plant Geography. Clarendon Press, Oxford, pp. 632.

Towsend CC and Guest E (Eds) 1966-1985. Flora of Iraq, Vols. 1-2-3-4-8-9. Ministry of Agriculture, Republic of Iraq, Baghdad.

Tüzüner A 1990. Laboratory Handbook of Soil and Water Analysis. Ministry of Agriculture, Forestry and Rural Affairs, Ankara. pp. 374.

Weber HE, Moravec J and Theurillat JP 2000. International code of phytosociological nomenclature, $3^{\text {rd }}$ edition. J. Veg. Sci. 11: 739-768.

Zohary M 1973. Geobotanical Foundations of the Middle East, Vols. 1-2. Gustav Fischer Verlag, Stuttgart. pp. 739.

Zohary M and Feinbrun-Dothan N (Eds) 1966-1986. Flora Palaestina, Vols. 1-4. Academic Press, Jerusalem. 